\title{
Pengaruh Model Pembelajaran Think Talk Write (TTW) Berbasis Literasi terhadap Keterampilan Menulis dalam Bahasa Indonesia
}

\author{
Ni Luh Putu Yuni Arista ${ }^{1^{*}}$, DB. Kt. Ngr. Semara Putra ${ }^{2}$ \\ ${ }^{12}$ Jurusan Pendidikan Guru Sekolah Dasar, Universitas Pendidikan Ganesha, Indonesia
}

\begin{tabular}{l} 
A R T I C L E I N F O \\
\hline Article history: \\
Received 18 May 2019 \\
Received in revised form \\
30 June 2019 \\
Accepted 15 July 2019 \\
Available online 25 August \\
2019 \\
\hline Kata Kunci: \\
pembelajaran TTW, \\
Literasi, keterampilan \\
menulis dalam bahasa \\
Indonesia \\
Keywords: \\
TTW learning model, \\
literary, writing skill in \\
Indonesian Language
\end{tabular}

\section{ARTICLEINFO}

Received in revised form Ac une 2019

Available online 25 August

Kata Kunci

iterasi, keterampila

menulis dalam bahasa

Keywords:

literary, writing skill in

Indonesian Language

\begin{abstract}
A B S T R A K
Penelitian ini bertujuan untuk mengetahui perbedaan yang signifikan keterampilan menulis dalam bahasa Indonesia antara kelompok siswa yang dibelajarkan menggunakan model pembelajaran TTW berbasis Literasi dengan kelompok siswa yang dibelajarkan dengan pembelajaran konvensional pada siswa kelas II SD Gugus VIII Abiansemal Tahun Pelajaran 2017/2018. Jenis penelitian ini adalah quasi eksperiment dengan menggunakan rancangan nonequivalent control group design. Populasi dalam penelitian ini adalah seluruh siswa kelas II SD Gugus VIII Abiansemal yang terdiri dari 9 kelas dengan jumlah populasi 224 orang siswa dari 8 Sekolah Dasar. Cara penentuan sampel penelitian ini dilakukan dengan teknik random sampling. Sampel dalam penelitian ini berjumlah 64 orang siswa. Metode pengumpulan data dalam penelitian ini adalah metode tes. Data yang dikumpulkan berupa nilai keterampilan menulis dalam bahasa Indonesia yang dianalisis menggunakan uji-t. Berdasarkan analisis data diperoleh hasil penelitian, menunjukkan terdapat perbedaan yang signifikan keterampilan menulis dalam bahasa Indonesia kelompok siswa yang dibelajarkan menggunakan model pembelajaran TTW berbasis Literasi dan kelompok siswa yang dibelajarkan menggunakan pembelajaran konvensional pada siswa kelas II SD Gugus VIII Abiansemal tahun pelajaran 2017/2018. Dengan demikian, dapat disimpulkan bahwa model pembelajaran TTW berpengaruh terhadap keterampilan menulis dalam bahasa Indonesia siswa kelas II SD Gugus VIII Abiansemal tahun pelajaran 2017/2018.
\end{abstract}

\section{A B S T R A C T}

This research was aimed at determining the significant difference of writing skill in Indonesian Language between the group of students taught using TTW Literary-based learning model and that taught using conventional learning of the second-grade students of Elementary School Gugus VIII Abiansemal in 2017/ 2018 academic year. This research was quasi-experiment using non-equivalent control group design. The population of the research was all of the second-grade students of Elementary School Gugus VIII Abiansemal consisting of 9 classes in which the total population was 224 students from 8 elementary schools. The samples in this research were chosen using random sampling technique consisting of 64 students. The data collection method in this research is test method. The collected data were in the form of students' writing skill in Indonesian languages which were analyzed using $T$ Test. Based on data analysis in the research result. It means that there is the significant difference on the writing skill in Indonesia language between the group of students taught using TTW-based literacy learning model and the group of students taught using conventional learning at the second-grade of Elementary School Gugus VIII Abiansemal in 2017/2018 academic year. Thus, it can be concluded that TTW learning model affects the writing skill in Indonesian Language of the second-grade students of Elementary School Gugus VIII Abiansemal in 2017/2018 academic year.

\footnotetext{
${ }^{1}$ Corresponding author.

E-mail addresses: yuni.arista90@undiksha.ac.id (Ni Luh Putu Yuni Arista)
} 


\section{Pendahuluan}

Bahasa merupakan alat komunikasi yang digunakan oleh setiap individu dalam kehidupan sehari hari. Bahasa dapat mengutarakan keinginan seseorang dan dapat mencurahkan perasaan, saling memahami pikiran, dan gagasan. Melalui berbahasa, manusia mampu berinteraksi dan berkomunikasi dengan masyarakat lainnya sehingga memungkinkan menciptakan kerja sama antar warga sehingga dapat dikatakan bahwa "bahasa merupakan alat komunikasi yang berupa sistem lambang bunyi yang dihasilkan alat ucap manusia”(Mulyati,2015:2).

Dalam dunia pendidikan, bahasa merupakan kunci penentu menuju keberhasilan dalam mempelajari bidang studi. Mengingat pentingnya bahasa dalam dunia pendidikan, maka di sekolah diterapkan pelajaran bahasa, salah satunya adalah pelajaran bahasa Indonesia. Bahasa Indonesia merupakan salah satu mata pelajaran yang wajib diberikan pada jenjang pendidikan formal, baik itu sekolah dasar, sekolah menengah maupun perguruan tinggi. Secara umum, tujuan dari adanya pelajaran bahasa Indonesia di Sekolah Dasar (SD) adalah "agar siswa mampu menikmati dan memanfaatkan karya sastra untuk mengembangkan kepribadian, memperluas wawasan kehidupan, serta meningkatkan pengetahuan dan kemampuan berbahasa"(Susanto,2013:245). Dalam pembelajaran bahasa Indonesia di SD siswa diajarkan empat keterampilan berbahasa yang merupakan modal terpenting yang harus dimiliki oleh siswa. Empat keterampilan berbahasa tersebut, yaitu menyimak, berbicara, membaca, dan menulis. "Keempat keterampilan tersebut dalam penggunaannya sebagai alat komunikasi tidak pernah dapat berdiri sendiri, satu sama lain saling berkaitan dan saling menentukan" (Dalman,2016:2). Dari keempat keterampilan berbahasa tersebut, keterampilan menulis merupakan keterampilan yang harus dikuasai siswa.

Menulis dapat didefinisikan "sebagai suatu kegiatan penyampaian pesan (komunikasi) dengan menggunakkan bahasa tulis sebagai alat atau medianya" (Suparno dan Yunus, 2007:1.3). Menulis adalah suatu keterampilan menuangkan ide- ide atau gagagsan dengan bahasa tulis melalui kalimat - kalimat yang dirangkai secara utuh, lengkap dan jelas sehingga ide atau gagasan tersebut dapat dikomunikasikan dengan baik kepada pembaca. Menulis dapat digunakan sebagai panduan untuk membantu siswa dalam membangkitkan ingatan dan pengetahuannya yang tersimpan dalam bawah sadar mereka sehingga keterampilan menulis sangat penting dikuasai oleh siswa guna menunjang keberhasilannya dalam pembelajaran.

Di SD, khususnya untuk siswa yang memasuki kelas II mulai ditanamkan dasar - dasar menulis karena jika dasarnya kuat dan dikuasai dengan benar maka siswa dapat menulis dengan baik dan benar dan siswa mampu menguasai keterampilan menulis. Akan tetapi, pembelajaran di sekolah saat ini belum mampu mewujudkan hal tersebut dan dari hal terkecil, terhadap minat menulis dalam muatan materi bahasa Indonesia anak SD masih sangat rendah yang dalam hal ini masih menjadi kendala yang dihadapi oleh guru. Kendala - kendala yang terjadi dapat dipengaruhi oleh berbagai faktor, salah satunya adalah kurangnya inovasi yang dilakukan guru dalam proses pembelajaran sehingga sebagai pelaksana pendidikan yang memegang peranan yang sangat penting, guru harus mampu mengemas pembelajaran yang menarik bagi siswa untuk menciptakan proses pembelajaran yang menyenangkan dan inovatif.

Berdasarkan observasi pada hari Jumat tanggal 12 Januari 2018 dan wawancara dengan seluruh guru kelas II SD di Gugus VIII Abiansemal Kecamatan Abiansemal ditemukan permasalahan yang menyebabkan rendahnya keterampilan menulis dalam pembelajaran bahasa Indonesia, yaitu (1) kurangnya penerapan model pembelajaran yang kreatif dan inovatif. Dari sembilan orang guru kelas II SD Gugus VIII Abiansemal yang diwawancarai beberapa guru diantaranya menyatakan jarang menggunakan model pembelajaran yang inovatif khususnya pada keterampilan menulis; (2) kurangnya media yang mendukung proses pembelajaran sehingga pembelajaran kurang menarik dan siswa merasa jenuh; (3) guru belum mampu memotivasi siswa yang tidak mau menulis, dan; (4) dari hasil pemeriksaan tulisan siswa kelas II SD, beberapa siswa kelas II SD belum mampu menyusun kalimat sesuai dengan pola, bentuk dan ukuran tulisannya belum rapi, dan belum mampu membuat tulisan yang bersih dan rapi; dan dan (5) dalam menulis kalimat sederhana siswa belum paham dalam penggunaan huruf kapital pada awal kalimat dan nama orang serta penggunaan tanda baca titik (.). Hal ini jika dibiarkan tentunya akan berpengaruh terhadap pencapaian keterampilan menulis dalam pembelajaran bahasa Indonesia siswa.

Sebagai salah satu alternatif untuk mengatasi permasalahan yang dihadapi guru dilapangan, peneliti menerapkan strategi pembelajaran untuk mengoptimalkan proses pembelajaran terhadap keterampilan menulis dalam bahasa Indonesia. Strategi tersebut adalah model pembelajaran Think Talk Write (TTW) berbasis Literasi.

Menurut Riski (2017) Model pembelajaran ini membuat siswa lebih berperan aktif dan berperan lebih dominan dibanding guru. Tugas guru dalam model pembelajaran TTW hanya sebagai fasilitator dan motivator dalam pembelajaran. Namun, guru sebagai fasilitator harus selalu memantau perkembangan 
aktivitas siswa dan mendorong siswa agar mencapai tujuan yang hendak dicapai. Menurut Setiyaningrum (2015) Model pembelajaran kooperatif tipe Think-Talk-Write (TTW) merupakan suatu model pembelajaran yang dibangun melalui tiga hal yaitu berpikir, berbicara, dan menulis. Alur pembelajaran model Think-Talk-Write (TTW) dimulai dari keterlibatan siswa dalam berpikir dan berdialog dengan dirinya sendiri setelah proses membaca, selanjutnya berbicara dan membagi ide (sharing) dengan temannya sebelum menulis. Menurut Hamdayama (2014:217) Think Talk Write adalah sebuah pembelajaran yang dimulai dengan berpikir melalui bahan bacaan (menyimak, mengkritisi, dan alternatif solusi), hasil bacaannya dikomunikasikan dengan presentasi, diskusi, dan kemudian membuat laporan hasil presentasi. Dalam proses pembelajaran siswa membaca suatu bacaan lalu berpikir dan membuat catatan kecil, dan kemudian menjelaskan kepada kelompoknya, sehingga setiap anggota kelompok saling menuangkan ide masing-masing, dan kemudian menuangkan hasil diskusi melalui tulisan. Sedangkan menurut Iru dan Arihi (2012:68) model pembelajaran Think Talk Write merupakan model pembelajaran dimana perencanaan dari tindakan yang cermat mengenai kegiatan pembelajaran yaitu melalui berpikir, bertukar pendapat, dan menuliskan hasil diskusi agar tujuan pembelajaran dapat tercapai. Menurut Hartanto (2017) model pembelajaran Think Talk Write menggunakan kelompokkelompok kecil dan menuntut siswa untuk bekerjasama, berdiskusi, berbagi ilmu pengetahuan, saling berkomunikasi, dan saling membantu untuk memahami materi pelajaran. Dalam model ini, siswa dituntut untuk melakukan tiga aktifitas, yaitu berpikir (think), berbicara (talk), dan menulis (write). Model pembelajaran TTW merupakan "suatu model pembelajaran untuk melatih keterampilan peserta didik dalam menulis"(Shoimin,2014:212). Menurut Huda (2013:218) TTW adalah "strategi yang memfasilitasi latihan berbahasa secara lisan dan menulis bahasa tersebut dengan lancar". Kelebihan dari model TTW, yaitu mengembangkan pemecahan yang bermakna dalam memahami materi ajar dan membiasakan siswa berpikir dan berkomunikasi dengan teman, guru, bahkan dengan diri mereka sendiri. Adapun sintak Model pembelajaran TTW ,yaitu Think (berpikir), Talk (berbicara), dan Write (menulis). Pada model pembelajaran ini, siswa diberikan peluang untuk berinteraksi antara sesama siswa selama pembelajaran berlangsung. Mengkolaborasikan model pembelajaran TTW Berbasis Literasi dirasa semakin efektif dalam pembelajaran. Literasi dipandang sebagai kemampuan membaca dan menulis. Orang yang dapat dikatakan literat dalam pandangan ini adalah orang yang mampu membaca dan menulis atau bebas buta huruf (Abidin dkk,2017:1).

Lipton (2016:13), menyatakan bahwa,

"Definisi literasi mencakup kemampuan berbahasam berhitung, memaknai gambar, melek komputer dan berbagai sarana dasar lainnya untuk berkomunikasi, memahami, menyampaikan, memperolej pengetahuan yang bernilai guna, dan mengambil manfaat dari berbagai sistem simbol yang dominan dari suatu budaya".

Dalam penelitian ini, pemanfaatan literasi dalam menunjang model pembelajaran TTW sangat membantu dalam segi pelaksanaannya. Selain kemampuan membuat pembelajaran bermakna, literasi juga dapat dikatakan sebagai kemampuan memproduksi berbagai ide.

Berdasarkan uraian sebelumnya, maka dilakukan penelitian yang berjudul "Pengaruh Model Pembelajaran Think Talk Write (TTW) Berbasis Literasi terhadap Keterampilan Menulis dalam Bahasa Indonesia Siswa Kelas II SD Gugus VIII Abiansemal Tahun Pelajaran 2017/2018”.

\section{Metode}

Penelitian ini dilaksanakan di SD Gugus VIII Abiansemal Kecamatan Abiansemal. Pemilihan SD Gugus VIII Abiansemal sebagai tempat penelitian karena keterjangkauan dan kelayakan. Keterjangkauan dalam arti tempat penelitian mudah dijangkau oleh peneliti, serta kelayakan dalam arti di SD Gugus VIII Abiansemal belum pernah dilakukan penelitian yang sama dengan penelitian ini. Penelitian ini dilaksanakan pada kelas II di SD Gugus VIII Abiansemal. Jenis penelitian yang digunakan dalam penelitian ini adalah quasi eksperiment (eksperimen semu) dengan menggunakan rancangan nonequivalent control group design.

Populasi adalah keseluruhan objek dalam suatu penelitian (Agung, 2014:69). Hal ini sejalan dengan Setyosari (2015:221) yang menyatakan bahwa populasi merupakan keseluruhan dari objek, orang, peristiwa, atau sejenisnya yang menjadi perhatian dan kajian dalam penelitian. Jadi dapat disimpulkan bahwa populasi adalah keseluruhan objek yang dijadikan kajian dalam penelitian. Populasi dari penelitian ini adalah seluruh siswa kelas II Gugus VIII Abiansemal tahun pelajaran 2017/2018 yang berjumlah 224 orang. Dari populasi yang telah ditentukan maka selanjutnya diambil perwakilan dari populasi tersebut yang dianggap mewakili seluruh populasi. Perwakilan yang mewakili seluruh populasi disebut sampel. 
Sampel merupakan "sejumlah kelompok kecil yang mewakili populasi untuk dijadikan sebagai objek penelitian" (Setyosari, 2015:221). Hal ini sejalan dengan pendapat Agung (2014:69) yang menyatakan, sampel ialah "sebagian dari populasi yang diambil, yang dianggap mewakili seluruh populasi dan diambil dengan menggunakan teknik tertentu". Jadi dapat disimpulkan bahwa sampel merupakan kelompok kecil yang mewakili populasi untuk dijadikan objek penelitian yang diambil dengan menggunakan teknik tertentu.

Dalam penelitian ini sampel yang dipilih adalah dua kelas, yaitu satu kelas eksperimen dan satu kelas kontrol. Kedua kelas tersebut nantinya akan diberikan perlakuan yang berbeda. Satu kelas akan diberikan perlakuan dengan model TTW berbasis literasi dan satu kelas lagi diberikan perlakuan menggunakan pembelajaran Konvensional. Pengambilan sampel dalam penelitian ini menggunakan teknik Random Sampling.

Untuk mendapatkan sampel, cara yang digunakan adalah dengan cara pengundian. Cara undian dilakukan dengan menulis semua nama sekolah beserta kelasnya pada masing-masing kertas, kemudian kertas digulung. Masukkan gulungan kertas ke dalam kotak dan dikocok. Ambil satu gulungan kertas, lalu ambil gulungan kertas lain, tanpa memasukkan gulungan kertas pertama. Nama sekolah beserta kelasnya pada kedua gulungan merupakan sampel penelitian. Kedua kelas yang terpilih menjadi sampel diberikan pre-test. Nilai atau skor dari hasil pre-test yang dilakukan, digunakan untuk penyetaraan kelas. Nilai atau skor dari hasil pre-test kedua kelas dianalisis menggunakan uji t. Setelah kelas setara, peneliti melakukan pengundian lagi dari kedua sampel untuk memilih kelas yang digunakan sebagai kelompok eksperimen dan kelompok kontrol.

Sampel dalam penelitian ini adalah siswa kelas II SD No. 1 Sibangkaja dengan jumlah 32 siswa sebagai kelompok eksperimen yang dibelajarkan menggunakan model pembelajaran TTW berbasis Literasi dan siswa kelas II SD No. 4 Sibanggede dengan jumlah 32 siswa sebagai kelompok kontrol yang dibelajarkan dengan pembelajaran konvensional. Instrumen untuk mengumpulkan data keterampilan menulis dalam bahasa Indonesia adalah menggunakan tes esai. Tes esai adalah "butir tes (soal) yang mengandung pertanyaan atau tugas, yang jawaban dan pengerjaan tugas tersebut harus dilakukan dengan cara mengekspresikan pikiran siswa secara tertulis"(Agung,2013:38).

Tes esai dengan jumlah pertanyaan, yaitu 1 butir soal. Setiap item diberikan skor minimal 0 dan skor maksimal 20. Skor setiap jawaban dijumlahkan dan jumlah tersebut menjadi skor variabel keterampilan menulis dalam bahasa Indonesia yang bergerak kisaran 0 -100. "Sebuah tes dikatakan valid apabila tes tersebut mengukur apa yang hendak diukur" (Agung, 2013:77). Uji validitas yang digunakan dalam penelitian ini yaitu validitas isi dan uji validitas konstrak. Validitas isi adalah "validitas dari segi isinya atau apabila mengukur tujuan khusus tertentu yang sejajar dengan isi atau materi pelajaran yang diberikan"(Agung, 2011:53). Validitas isi berkenaan dengan kesanggupan instrumen mengukur isi yang harus diukur. "Artinya instrumen tersebut mampu mengungkap isi suatu konsep atau variabel yang hendak diukur" (Agung, 2014:193). Uji validitas isi dalam penelitian ini adalah menyusun soal berdasarkan kisi - kisi yang materinya disesuaikan dengan kurikulum dan bahan pembelajaran dalam penelitian. "Instrumen yang mempunyai validitas konstruksi, jika instrumen tersebut dapat digunakan untuk mengukur gejala sesuai dengan yang didefinisikan"(Sugiyono,2015:176). Dalam hal ini, setelah instrumen dikonstruksi tentang teori tertentu, maka selanjutnya dikonsultasikan dengan ahli. "Untuk menguji validitas konstrak, maka dapat digunakan pendapat dari ahli (judgment experts)" (Sugiyono,2017:352).

Data yang diperoleh dalam penelitian ini adalah keterampilan menulis dalam bahasa Indonesia kelas II, yang berasal dari nilai post-test kelompok eksperimen dan kelompok kontrol. Kedua data ini kemudian dianalisis menggunakan teknik analisis statistik deskriptif dan teknik analisis statistik inferensial. Teknik analisis statistik deskriptif dalam penelitian ini digunakan untuk mendeskripsikan data keterampilan menulis dalam bahasa Indonesia siswa yang dibelajarkan dengan model pembelajaran TTW berbasis Literasi, dan keterampilan menulis dalam bahasa Indonesia siswa yang dibelajarkan dengan pembelajaran konvensional. Dalam penelitian ini dilakukan penghitungan mean, standar deviasi, dan varians.

Analisis Statistik Inferensial adalah"teknik statistik yang digunakan untuk menganalisis data sampel dan hasilnya diberlakukan untuk populasi"(Sugiyono,2017:148). Menurut Sukardi (2011:154) "statistik inferensial yaitu teknik statistika dalam pembuatan keputusan tentang populasi yang diteliti berdasarkan kepada data yang diperoleh dari sampel". Dari beberapa pendapat ahli, dapat disimpulkan bahwa statistik inferensial adalah statistik yang digunakan untuk menganalisis data sampel dalam rangka penarikan kesimpulan mengenai populasi. Teknik analisis data yang dilakukan adalah uji hipotesis menggunakan uji t, sebelum dilakukan uji hipotesis, terlebih dahulu dilakukan uji prasyarat analisis data, yaitu uji prasyarat analisis yang meliputi uji normalitas sebaran data dengan kriteria pengujian, yaitu taraf signifikansi 5\% dengan derajat kebebasannya $(\mathrm{dk})=\mathrm{k}-1=6-1=5$ adalah jika jika $\chi_{\text {hitung }}^{2} \leq \chi_{\text {tabel }}^{2}$, maka 
$\mathrm{H}_{\mathrm{o}}$ diterima (gagal ditolak) yang berarti data berdistribusi normal dan homogenitas varians dengan kriteria pengujian, jika $\mathrm{F}_{\text {hit }}<\mathrm{F}_{\text {tabel }}$ maka sampel homogen. Pengujian dilakukan pada taraf signifikansi 5\% dengan derajat kebebasan untuk pembilang $n_{1}-1$ dan derajat kebebasan untuk penyebut $\mathrm{n}_{2}-1$. Kemudian data yang telah diuji normalitasnya dan homogenitasnya, selanjutnya dilakukan uji hipotesis menggunakan uji $t$ dengan rumus polled varians. Dengan kriteria jika harga $t_{\text {hitung }}<t_{\text {tabel, }}$, maka $\mathrm{H}_{\mathrm{o}}$ diterima dan $\mathrm{H}_{\mathrm{a}}$ ditolak, dan jika harga $\mathrm{t}_{\text {hitung }}>\mathrm{tt}_{\text {abel }}$ maka $\mathrm{H}_{\mathrm{o}}$ ditolak dan $\mathrm{H}_{\mathrm{a}}$ diterima. Pada taraf signifikansi $5 \%$ $(\alpha=0,05)$ dengan $\mathrm{dk}=\mathrm{n}_{1}+\mathrm{n}_{2}-2$. Adapun rumus uji t dengan rumus polled varian sebagai berikut.

$$
t=\frac{\overline{X_{1}}-\overline{X_{2}}}{\sqrt{\frac{\left(n_{1}-1\right) s_{1}{ }^{2}+\left(n_{2}-1\right) s_{2}{ }^{2}}{n_{1}+n_{2}-2}\left(\frac{1}{n_{1}}+\frac{1}{n_{2}}\right)}}
$$

(Sugiyono, 2015:273)

\section{Hasil dan Pembahasan}

Adapun hasil analisis data baik kelompok eksperimen dan kelompok kontrol disajikan dalam Tabel 1.

Tabel 1. Deskripsi Keterampilan Menulis dalam Bahasa Indonesia

\begin{tabular}{|c|c|c|}
\hline Statistik Data & Kelompok Eksperimen & Kelompok Kontrol \\
\hline Mean & 86,25 & 70,94 \\
\hline Varians & 53,23 & 50,71 \\
\hline Standar Deviasi & 7,30 & 7,12 \\
\hline Nilai Minimum & 70 & 55 \\
\hline Nilai Maksimum & 95 & 85 \\
\hline
\end{tabular}

Berdasarkan Tabel 1 tersebut, nilai mean atau rata-rata keterampilan menulis dalam bahasa Indonesia siswa yang mengikuti pembelajaran menggunakan model pembelajaran TTW berbasis Literasi, yaitu $\bar{x}=86,25$, dengan varians 53,23 dan standar deviasi 7,30. Sedangkan nilai mean atau rata-rata keterampilan menulis dalam bahasa Indonesia siswa yang dibelajarkan dengan pembelajaran konvensional yaitu $\bar{x}=70,94$, dengan varians 50,71 dan standar deviasi 7,12. Perhitungan analisis data hasil penelitian yang diperoleh menunjukkan bahwa keterampilan menulis dalam bahasa Indonesia kelompok eksperimen, yaitu siswa yang dibelajarkan menggunakan model pembelajaran TTW berbasis Literasi memiliki nilai mean lebih tinggi daripada kelompok control, yaitu siswa yang dibelajarkan dengan pembelajaran konvensional, yaitu $\bar{x}=86,25>\bar{x}=70,94$.

Data yang diperoleh dari hasil post-test kemudian dianalisis menggunakan statistik melalui tahapan meliputi uji normalitas, uji homogentitas, dan uji hipotesis Maka harus dilakukan beberapa uji prasyarat terhadap sebaran data yang meliputi uji normalitas dan uji homogenitas varians. Hasil uji normalitas kelompok eksperimen, diperoleh Chi Kuadrat hitung $\left(\mathrm{X}^{2}{ }_{\text {hitung }}=6,25\right)$ kemudian nilai tersebut dibandingkan dengan Chi Kuadrat tabel $\left(\mathrm{X}^{2}\right.$ tabel $\left.=11,07\right)$. Hal ini menunjukkan bahwa $\mathrm{X}^{2}{ }_{\text {hitung }}<\mathrm{X}^{2}{ }_{\text {tabel }}$ berarti data hasil keterampilan menulis dalam bahasa Indonesia kelompok eksperimen berdistribusi normal..

Hasil uji normalitas kelompok kontrol, diperoleh Chi Kuadrat hitung $\left(\mathrm{X}^{2}\right.$ hitung $\left.=10,09\right)$ kemudian nilai tersebut dibandingkan dengan Chi Kuadrat tabel $\left(\mathrm{X}^{2}\right.$ tabel $\left.=11,07\right)$. Hal ini menunjukkan bahwa $\mathrm{X}^{2}$ hitung $<\mathrm{X}^{2}$ tabel berarti data hasil keterampilan menulis dalam bahasa Indonesia kelompok kontrol berdistribusi normal... Homogenitas varians data keterampilan menulis dalam bahasa Indonesia dianalisis dengan uji $\mathrm{F}$. Dari hasil analisis, diperoleh $F_{\text {hitung }}=1,04$ dan $F_{\text {tabel }}=1,84$. Hal ini berarti $F_{\text {hitung }}<F_{\text {tabel }}$, sehingga data kedua kelompok memiliki varians yang homogen. Hipotesis yang diuji dalam penelitian ini adalah tidak terdapat perbedaan yang signifikan keterampilan menulis dalam bahasa Indonesia antara kelompok siswa yang dibelajarkan melalui model pembelajaran TTW berbasis Literasi dengan kelompok siswa yang dibelajarkan melalui pembelajaran konvensional pada kelas II SD Gugus VIII Abiansemal Tahun Pelajaran 2017/2018. Kriteria pengujian adalah Ho ditolak jika $t_{\text {hitung }}>t_{\text {tabel }}$ dimana $t_{\text {tabel }}$ diperoleh dari tabel 
distribusi t pada taraf signifikan 5\% dengan dk $(\mathrm{n} 1+\mathrm{n} 2)-2$. Rangkuman hasil analisis uji-t ditunjukkan pada Tabel 2 .

Tabel 2. Rangkuman Hasil Analisis Uji-t

\begin{tabular}{clcccccc}
\hline No & Kelompok Sampel & $\mathbf{N}$ & $\mathbf{D k}$ & $\overline{\mathbf{x}}$ & $\mathbf{t}_{\text {hitung }}$ & $\mathbf{t}_{\text {tabel }}$ & Keterangan \\
\hline 1 & Eksperimen & 32 & 62 & 86,25 & \multirow{2}{*}{8,494} & \multirow{2}{*}{2,000} & \multirow{2}{*}{$\mathrm{H}_{\mathrm{o}}$ ditolak } \\
2 & Kontrol & 32 & & 70,94 & & \\
\hline
\end{tabular}

Berdasarkan uji hipotesis diperoleh $t_{\text {hitung }}=8,949$ sedangkan pada taraf signifikansi $5 \%$ dan $\mathrm{dk}=62$ diperoleh nilai $t_{\text {tabel }}=2,000$ sehingga $t_{\text {hitung }}=8,949>t_{\text {tabel }}=2,000$. Dengan demikian, hipotesis nol $\left(H_{0}\right)$ ditolak. Hal ini berarti terdapat perbedaan yang signifikan keterampilan menulis dalam bahasa Indonesia antara siswa kelas II SD Gugus VIII Abiansemal tahun pelajaran 2017/2018 yang mengikuti pembelajaran dengan menggunakan model pembelajaran TTW berbasis Literasi dan siswa yang mengikuti pembelajaran konvensional. Perolehan hasil perhitungan analisis data yang dilakukan menunjukkan bahwa nilai rerata siswa yang mengikuti pembelajaran menggunakan model TTW berbasis Literasi $(\overline{\mathrm{x}}=$ $86,25)$ dan siswa yang mengikuti pembelajaran konvensional $(\overline{\mathrm{x}}=70,94)$ memiliki perbedaan sebesar 15,31, dengan demikian terdapat pengaruh keterampilan menulis dalam bahasa Indonesia antara siswa kelas II SD Gugus VIII Abiansemal Tahun Pelajaran 2017/2018 yang mengikuti pembelajaran dengan menggunakan model pembelajaran TTW berbasis Literasi dan siswa yang mengikuti pembelajaran konvensional.

Berdasarkan hasil temuan tersebut, dapat dinyatakan kedua kelompok sampel penelitian yang memiliki kemampuan setara, setelah diberikan perlakuan berupa pembelajaran dengan menggunakan model pembelajaran TTW berbasis Literasi dan mengikuti pembelajaran konvensional diperoleh hasil keterampilan menulis dalam bahasa Indonesia yang berbeda. Hal ini dapat dilihat juga dari rata -rata siswa yang mengikuti pembelajaran menggunakan model pembelajaran TTW berbasis Literasi lebih tinggi dibandingkan dengan rata - rata siswa yang mengikuti pembelajaran konvensional. Perbedaan hasil keterampilan menulis dalam bahasa Indonesia dapat dilihat dari perolehan nilai rerata yang lebih tinggi pada kelompok eksperimen dibandingkan kelompok kontrol disebabkan oleh perlakuan yang diberikan pada kelompok eksperimen berupa model pembelajaran TTW berbasis Literasi dalam keterampilan menulis dalam bahasa Indonesia.

Pada kelompok eksperimen, kegiatan pembelajaran keterampilan dalam bahasa Indonesia menggunakan model pembelajaran TTW berbasis Literasi berjalan dengan optimal dan kondusif. Hal ini disebabkan karena pembelajaran dengan model TTW berbasis Literasi memancing rasa ingin tahu siswa terhadap suatu bahasan yang dilakukan. Selain itu model ini juga dapat memancing setiap siswa untuk saling berkomunikasi, mengemukakan ide - ide dan gagasan - gagasan yang kemudian dapat dituangkan ke dalam bahasa tulis.

Adanya pengaruh baik dari model pembelajaran TTW berbasis Literasi ini, juga didasari oleh teori teori yang ada salah satunya oleh Huda. Menurut Huda (2013 :218) menyatakan bahwa model TTW mendorong siswa untuk berpikir, berbicara, dan kemudian menuliskan suatu topik tertentu. Model ini digunakan untuk mengembangkan tulisan, melatih bahasa anak, mempengaruhi dan memanipulasi ide ide sebelum menuangkannya dalan bentuk tulisan.

Hasil temuan pada penelitian ini memiliki persamaan dengan penelitian sebelumnya yang relevan dan memperkuat hasil penelitian yang diperoleh. Hal tersebut didukung hasil penelitian yang diajukan oleh Sugiarti (2014) bahwa terdapat perbedaan yang signifikan pada hasil belajar bahasa Indonesia antara kelompok siswa yang dibelajarkan menggunakan model pembelajaran TTW (Think Talk Write) berbantuan media gambar berseri dengan kelompok siswa yang dibelajarkan menggunakan model pembelajaran konvensional. Hasil penelitian lain yang mendukung penelitian ini adalah penelitian yang diajukan oleh Sugiarta (2017) yang menyatakan bahwa terdapat perbedaan yang signifikan pada penguasaan kompetensi pengetahuan IPA antara kelompok siswa yang dibelajarkan menggunakan model pembelajaran TTW (Think Talk Write) berbantuan media lingkungan dengan kelompok siswa yang dibelajarkan menggunakan model pembelajaran konvensional. Dengan demikian, pembelajaran menggunakan model pembelajaran TTW berbasis Literasi pada penelitian ini memiliki keunggulan yakni dapat meningkatkan kemampuan berpikir dan interaksi antar siswa serta adanya perkembangan karakter siswa yang didasari dengan adanya Literasi.

Berdasarkan pemaparan tersebut, dapat disimpulkan bahwa model pembelajaran TTW berbasis Literasi berpengaruh terdapat keterampilan menulis dalam bahasa Indonesia siswa kelas II SD Gugus VIII Abiansemal Tahun Pelajaran 2017/2018. 


\section{Simpulan dan Saran}

Berdasarkan hasil analisis data dan pembahasan dapat dikemukakan simpulan sebagai berikut. Berdasarkan hasil analisis data keterampilan menulis dalam bahasa Indonesia siswa pada kelompok eksperimen yang diberikan perlakuan berupa model pembelajaran TTW Berbasis Literasi, diketahui bahwa nilai rata - rata kelompok eksperimen $\overline{\mathrm{x}}=86,25$ dengan perolehan nilai minimum 70 dan nilai maksimum 95 dan hasil analisis data keterampilan menulis dalam bahasa Indonesia siswa pada kelompok kontrol yang dibelajarkan menggunakan pembelajaran konvensional, diketahui bahwa nilai rata - rata kelompok kontrol $\overline{\mathrm{x}}=70,94$ dengan perolehan nilai minimum 55 dan nilai maksimum 85. Dari hasil uji hipotesis yang telah dilakukan dengan berdasarkan taraf signifikansi $5 \%$ dengan dk $=32+32-2=62$ diperoleh $t_{\text {tabel }}=2,000$ dan setelah di analisis diperoleh $t_{\text {hitung }}=8,494$. Hal ini berarti hipotesis nol $\left(\mathrm{H}_{\mathrm{o}}\right)$ ditolak sehingga dapat disimpulkan bahwa terdapat perbedaan yang signifikan keterampilan menulis dalam bahasa Indonesia antara kelompok siswa yang dibelajarkan dengan model pembelajaran TTW Berbasis Literasi dengan kelompok siswa yang dibelajarkan dengan pembelajaran konvensional pada siswa kelas II SD Gugus VIII Abiansemal. Hal tersebut berarti, model pembelajaran TTW Berbasis Literasi berpengaruh terhadap keterampilan menulis dalam bahasa Indonesia siswa kelas II SD Gugus VIII Abiansemal Tahun Pelajaran 2017/2018.

Berdasarkan hasil analisis data dan simpulan, maka saran yang dapat disampaikan, yaitu sebagai berikut. Kepada Guru, guru hendaknya dapat menambah wawasannya mengenai inovasi pembelajaran dan memilih model pembelajaran yang inovatif guna menunjang kegiatan pembelajaran kearah yang lebih baik demi tercapainya peningkatan keterampilan menulis siswa dalam bahasa Indonesia. Salah satu model pembelajaran yang dapat direkomendasikan untuk guru dalam menciptakan pembelajaran yang bervariasi adalah dengan menerapkan model pembelajaran TTW Berbasis Literasi. Kepada Kepala Sekolah, Kepala Sekolah disarankan berkontribusi penuh dalam meningkatkan kualitas serta mengoptimalkan proses pembelajaran sehingga berdampak positif pada keterampilan menulis siswa dalam bahasa Indonesia di sekolah dasar. Kepada peneliti lain, disarankan agar hasil penelitian ini dapat digunakan sebagai suatu acuan bagi peneliti lain untuk mengembangkan kemampuan diri dalam mempersiapkan diri sebagai calon pendidik dan meningkatkan pemahaman penerapan model pembelajaran TTW Berbasis Literasi.

\section{Daftar Rujukan}

Abidin,Yunus,dkk. 2017. Pembelajaran Literasi Strategi Meningkatkan Kemampuan Literasi Matematika, Sains,Membaca,dan Menulis. Cetakan Pertama. Jakarta:Bumi Aksara.

Arikunto,Suharsimi. 2014. Prosedur Penelitian. Jakarta : Rineka Cipta.

Agung,A.A.G. 2011. Pengantar Evaluasi Pendidikan. Singaraja : Universitas Pendidikan Ganesha.

Agung ,A.A.G. 2012. Metodologi Penelitian Pendidikan. Cetakan Pertama. Singaraja : Aditya Media Publising.

Agung,A.A.G. 2013. Buku Ajar Evaluasi Pendidikan. Singaraja: FIP Undiksha.

Agung,A.A.G. 2014. Buku Ajar Metodologi Penelitian Pendidikan. Singaraja : FIP Undiksha.

Dalman.2016. Keterampilan Menulis. Jakarta : PT. Raja Grafindo Persada.

Dantes, Nyoman. 2012. Metode Penelitian. Yogyakarta : CV. Andi Offset.

Dantes,Nyoman. 2017. Desain Eksperimen dan Analisis Data. Depok : Rajawali Pres.

Hamdayama, Jumanta. 2014. Model Dan Metode Pembelajaran Kreatif Dan Berkarakter. Bogor: Ghalia Indonesia.

Hartanto. 2017. Penerapan Model Pembelajaran Think Talk Write (TTW) dengan Bantuan Lembar Kerja Siswa untuk Meningkatkan Aktivitas dan Hasil Belajar IPA Terpadu Siswa Kelas VII A SMP Negeri 2 Rantau Panjang. Jurnal Inovasi Dan Pembelajaran Fisika Vol. 4 No. 1 Hal. 10-17. http://fkip.unsri.ac.id/index.php/menu/104. 
Huda,Miftahul.2013.Model - Model Pengajaran dan Pembelajaran. Cetakan I. Yogyakarta : Pustaka Pelajar.

Iru, La dan Arihi L.S. 2012. Analisis Penerapan Pendekatan, Metode, Strategi, dan Model-model Pembelajaran. Jogjakarta : Multi Presindo.

Koyan, I Wayan.2012.Statistik Pendidikan Teknik Analisis Data Kuantitatif. Singaraja:Universitas Pendidikan Ganesha.

Lipton,Laura. 2016. Sekolah Literasi Perencanaan dan Pembinaan. Cetakan I. Bandung : Nuansa.

Mulyati. 2015. Terampil Berbahasa Indonesia Untuk Perguruan Tinggi. Cetakan I. Jakarta: Pernadamedia Group.

Ngalimun, 2016. Strategi dan Model Pembelajaran. Yogyakarta : Aswaja Pressindo.

Rasana, Raka. 2009. Laporan Sabbatical Leave Model - Model Pembelajaran. Singaraja : Universitas Pendidikan Ganesha.

Priyanti,Saras. 2017. Pengaruh Keterampilan Dasar Literasi Berbantuan Media Grafis Terhadap Penguasaan Kompetensi IPS Siswa Kelas IV SD Gugus I Gusti Ngurah Rai Kecamatan Denpasar Barat Tahun Pelajaran 2016/2017. Singaraja : FIP Undiksha. Tersedia pada : http://ejournal.undiksha.ac.id/index.php/JET/article/dwonload/11772/7530 (diakses pada tanggal 5 Januari 2018).

Riski, Riska, Muh. Rizal, Linawati. 2017. Penerapan Model Pembelajaran Kooperatif Tipe Think Talk Write (TTW) untuk Meningkatkan Hasil Belajar Siswa pada Materi Hubungan Sudut Pusat, Panjang Busur, dan Luas Juring di Kelas VIII C SMP Negeri 9 Palu. Jurnal elektronik Pendidikan Matematika Tadulako, Volume 5 Nomor 2, Hal. 175-190. Tersedia Pada: http://jurnal.untad.ac.id/jurnal/index.php/JEPMT/article/view/9097.

Semi,Atar. 2007. Dasar - Dasar Keterampilan Menulis. Bandung : Angkasa.

Setiyaningrum, Erin, dan Istiqomah. 2015. Efektivitas Penerapan Model Pembelajaran Think - Talk - Write terhadap Prestasi Belajar Matematika Siswa Kelas VII SMP Negeri 3 Magelang. UNION: Jurnal Pendidikan Matematika Vol 3 No 1 Hal. 9-16. Tersedia Pada: http://jurnal.ustjogja.ac.id/index.php/union/article/view/270.

Setyosari,Punaji.2015. Metode Penelitian Pendidikan dan Pengembangan. Edisi Keempat. Jakarta : Prenadamedia Group.

Shoimin,Aris. 2014. 68 Model Pembelajaran Inovatif dalam Kurikulum 2013. Cetakan Pertama. Yogyakarta : Ar-Ruzz Media.

Slamet.2014. Pembelajaran Keterampilan Berbahasa Indonesia. Edisi Kedua. Yogyakarta : Graha Ilmu

Sugiarta, Sang Made.(2017)."Pengaruh Model Pembelajaran TTW Berbantuan Media Lingkungan terhadap Penguasaan Kompetensi Pengetahuan IPA Siswa Kelas IV". E-Journal Mimbar PGSD Universitas

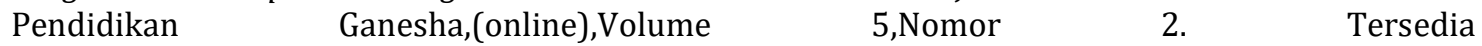
padahttp://ejournal.undiksha.ac.id/index.php/JJPGSD/article/viewFile/10764/6866 (diakses tanggal 9 Januari 2018).

Sugiarti, Yeni.(2014)."Pengaruh Model Pembelajaran TTW (Think Talk Write) Berbantuan Media Gambar Berseri terhadap Keterampilan Menulis Bahasa Indonesia Siswa Kelas V SD Gugus I Kecamatan Kediri Tahun Pelajaran 2013/2014". E-Journal Mimbar PGSD Universitas Pendidikan Ganesha,(online),Volume $\quad$ 2,Nomor $\quad 1 . \quad$ Tersedia padahttp://id.portalgaruda.org/?ref=search\&mod=document\&select=title\&q=Pengaruh + model $+\mathrm{t}$ hink+talk+write+terhadap+keterampilan+menulis\&button=Search+Document (diakses tanggal 9 Januari 2018). 
Sugiyono. 2012. Metode Penelitian Pendidikan Pendekatan Kuantitatif,Kualitatif, dan R\&D. Cetakan-21. Bandung : Alfabeta.

Sugiyono. 2015. Metode Penelitian Pendidikan Pendekatan Kuantitatif,Kualitatif, dan R\&D. Cetakan-21. Bandung : Alfabeta.

Sugiyono. 2017. Statistika Untuk Penelitian. Bandung : Alfabeta.

Sukardi. 2011. Evaluasi Pendidikan Prinsisp \& Operasionalnya. Jakarta Timur : Bumi Aksara.

Suparno, Yunus. 2007. Keterampilan Dasar Menulis. Cetakan Keempat. Jakarta : Universitas Terbuka.

Susanto, Ahmad. 2013. Teori Belajar dan Pembelajaran di Sekolah Dasar. Cetakan Pertama. Jakarta : Prenadamedia Group.

Taufina. 2016. Pembelajaran Bahasa dan Apresiasi Sastra Indonesia. Cetakan Pertama. Bandung : CV.Angkasa.

Trianto.2007. Model - Model Pembelajaran Inovatif Berorientasi Konstruktivitik. Cetakan Pertama. Jakarta : Prestasi Pustaka Publisher. 